\title{
THE USE OF DIGITAL STORYTELLING TOWARDS STUDENTS' COMPETENCY IN WRITING TEXT
}

\author{
Karisma Erikson Tarigan ${ }^{1)}$ and Liana ${ }^{2)}$ \\ ${ }^{1,2}$ FKIP Of Catolic University Of Saint Thomas Medan Indonesia \\ ${ }^{1,2}$ Jl. Setia Budi No. 479-F Tanjung Sari Medan, 20132 \\ E-mail: unikasintthomas.secretariat@gmail.com ${ }^{1)}$, lianasiburian302@yahoo.com ${ }^{2)}$
}

\begin{abstract}
The main objective of this research is to prove whether the digital storytelling enhances and improve students writing competency. The study uses classroom action research (CAR). The data in this study are quantitative and qualitative data. The quantitative data will be collected by using the essay test. The qualitative data will be collected by using observation, field notes, and questionnaire. The score of students' writing descriptive text kept increasing from pre-test until post-test. It was proved by the data which showed that the mean of the students' score in post-test II is $86.6(92.75 \%)$ was higher than the post-test I is $72.2(68.75 \%)$, and also higher than the pre-test $54.8(25 \%)$. The response of student in using digital storytelling in the agree category, it can be seen from the 15 students who passed the KKM (70) and 1 student still low of KKM. The class percentages of post-test II show improvements from the previous test; the improvement is $67.75 \%$. The frequencies of item agree appear 110 times or $(52.88 \%)$. Furthermore, it can be concluded that Digital Storytelling is effective and useful to be used in teaching writing skill, especially in Descriptive Text.
\end{abstract}

Keywords: Digital Storytelling, Writing Skill, Descriptive Text

\section{INTRODUCTION}

The subject of English writing is present throughout the teaching and learning in the education curriculum in Indonesia. Teacher in every content area can use writing as a powerful learning tool to help students' reflect on what they read, what they listen to, and work out their own thinking and through a process on paper. Furthermore, in the process of teaching and learning English as a foreign language, writing is very complex and the most crucial skill in learning English.

The teachers nowadays are not supposed to only give information to the conventional technique. The teacher must provide a media since the students-centered learning at university is applied in English Curriculum. Besides that, writing requires texts as the product of writing, so that students must able to write kinds of text. The most text in the Writing I until IV Subjects from the first to the fourth semester are Narrative, Descriptive, Recount and Report Text. In fact, based on preliminary observation and experience of the writer, there are some problems and difficulties that students face in writing a text. The most difficult part of writing is could not organize the development of their ideas and the purpose of the text.

The difficulty of complexity writing text can be seen from students' ignorance to the mechanical requirements such spelling, punctuation in making the cohesion and the coherence of writing clearly to get the purpose of the text. Therefore, it is crucial for teachers to facilitate students with some effective techniques and tools. And one of the tools is by using multimedia to present a text. The learning media contributes to the teaching and learning process.

Considering the issues that have been described, the writer tried to use multimedia which can encourage the students to enhance and improve their writing competency in the First Year of English Language Study Program Teacher Training and Education Faculty Catholic University of Saint Thomas Medan by using Digital Storytelling.

\section{THE SCOPE OF RESEARCH}

The learning media contributes to the teaching and learning process. With the development of information technology and the media development, the traditional story of application in teaching is increasingly reduced, technology during the presentation of the story began to play a role, so that the way of telling the story is more and more abundant, spreading more and more widely (Xie and Huang, 2012).

In line with the story, Students love putting the stories together with images and music on the computer, but before they get there, they must do the writing 
(Miller, 2010). Writing is thinking, so through writing, they find out what they want to say and how they want to say it in the scripts. Even though the visuals are an important part of digital stories, this thinking/writing is what digital stories are built on. The process will help them see themselves as writers. It will help them get the writing done. And it will make the stories stronger than if students concentrated mostly on the images instead of on the writing. Stories have been described as a way of passing down heritage, tradition, and culture for future generations. Storytelling can be a powerful pedagogic approach to motivate and engage students, especially in foreign and community language teaching. A digital story can be viewed as a merger between traditional storytelling and the use of multimedia technology (Anderson and Macleroy, 2016).

Digital storytelling is one of the multimedia to improve students' writing competency. Digital storytelling is also an effective vehicle for teaching another kind of literacy that is becoming increasingly important as our students spend more and more time in a media-saturated culture: media literacy (Ohler, 2008). Through digital storytelling, students can present the content of writing clearly, as well as the writer's purpose of the text. It is accurate because the stimulation of visual images, audio, and video in digital storytelling can help students express their ideas in writing text.

\section{METHODOLOGY AND DESIGN}

The study uses classroom action research (CAR). The data of this study are quantitative and qualitative data. The quantitative data will be collected by using essay test. The qualitative data will be collected by using observation, field notes and questionnaire. This study also involves four phases in each cycle which are essential as proposed by Kemmis and McTaggart (in Burns, 2010). Figure 1 shows, action research is carried out by teachers in their context, in their classrooms (Burns, 2010). Teachers identify a problem or an area they wish to improve and based on theory or experience or a hypothesis they think of an intervention. They document the intervention and results of it. If the results are positive, they could lead to the dissemination of the information. If not, the cycle may be started again." Those phases are planning, acting, observing, and reflecting. Planning is the identification process of problems or issues in order to compose a plan of action to bring improvements in a certain area of the research context. The action is the plan that is carefully considered one which includes some deliberate interventions into the teaching process. The next is observation. This phase involves the researcher in observing systematically the effect of the action and documenting all the process. The last phase is the reflection. At this phase, the researcher reflects on, evaluate and explain the effect of the action in order to make sense of what has happened and to understand the issue clearly.

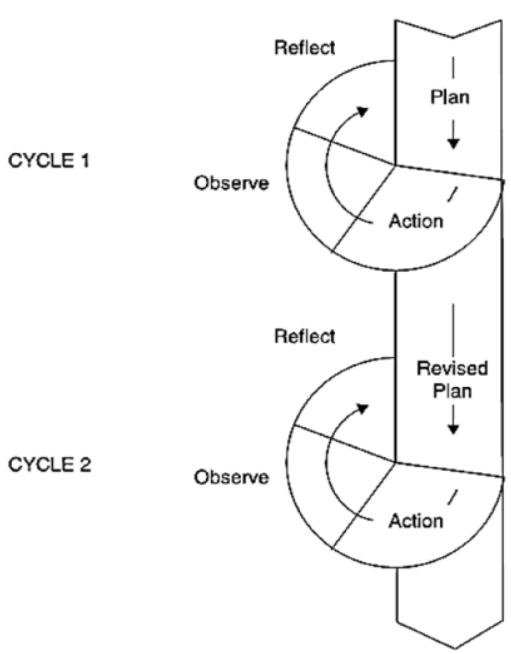

Figure 1. Cyclical Classroom Action Research (CAR) model based on Kemmis and McTaggrat in (Burns, 2010)

There will be three kinds of instruments used to get the data. They are observation sheet, field notes, and test form. Observation sheet and field notes will be used to get qualitative data and to obtain quantitative data, test and questionnaire will be used.

\subsection{Population and Sample Of Research}

This research will be conducted in the first semester of Students University of English Language Study Program Faculty of Teachers Training and Education Catholic University of Saint Thomas North Sumatera (FKIP UNIKA).

\subsection{Technique data collecting}

There will be three kinds of instruments used to get the data. They are observation sheet, field notes, and test form. The test is used to measure whether there will be an improvement of students' competency in writing skill by using digital storytelling. The kind of test is in the essay form. The questionnaire is given to know the students' motivation and response after they have been applied Digital Storytelling. The form of questionnaire is close-ended statements. Questionnaire is in the form of table which is filled out by giving sign of check mark $(\sqrt{ })$. Observation sheet is used to monitor and record the data of the students' performance and behavior during learning and teaching process in the class. The format of the observation checklist is close-ended statement. Observation is in the form of table which is filled out by giving sign of check mark $(\sqrt{ })$. The field notes contain the descriptions and accounts of events during the implementation of digital storytelling. It can be used by the writer to determine the best actions. 


\subsection{Technique Data Analysis}

The test will be analyzed to find out the improvement of students' writing competency after they are applied Digital Storytelling. The total score of writing test is illustrated by the following table 1 .

Table 1. Scoring Table of Writing Competency

\begin{tabular}{|l|l|c|}
\hline No. & $\begin{array}{l}\text { Writing } \\
\text { Elements }\end{array}$ & $\begin{array}{l}\text { Maximum } \\
\text { Score }\end{array}$ \\
\hline 1. & Content & 30 \\
\hline 2. & Organization & 20 \\
\hline 3 & Vocabulary & 20 \\
\hline 4. & Language Use & 25 \\
\hline 5. & Mechanics & 5 \\
\hline \multicolumn{2}{|c|}{ Total Score } & $\mathbf{1 0 0}$ \\
\hline
\end{tabular}

To know the mean of students' score, the writer uses the formula (1) by Best and Khan (2002):

$$
M=\frac{\sum \mathrm{X}}{N} \times 100 \%
$$

Where:

$\mathrm{M}=$ the mean of students' score

$\sum \mathrm{X}=$ the total score

$\mathrm{N}=$ the total number of students who do the test

The writer will analyze questionnaire in the form of numbers. Each item are categorized into 5 options, namely strongly disagree (sangat tidak setuju), disagree (tidak setuju), undecided (netral), agree (setuju), andstrongly agree (sangat setuju). The answers of questionnaire are scored by using the rating scale 1-5 ( score of strongly disagree $=1$, disagree $=2$, undecided $=3$, agree $=4$, and strongly agree $=5$ ). The data will be analyzed based on Yes or No checklist. Then, the writer will draw the conclusion about the students' performance and behavior in writing competency after they are applied with Digital Storytelling.

\section{RESULT AND DISCUSSION}

Based on the calculation the students mean score and the class percentage, the explanation of the data result among the pre-test, the post-test I, and the post-test II as following table 2 .

Before the writer using CAR, the mean score of the pre-test' students is 54.8 meanwhile, the class percentage of students who pass the KKM is $25 \%$. It can be said that from 16 students, there are only 4 students who pass the KKM (70). In addition, the mean score of the posttest after using Digital Storytelling technique, there are some improvement of students' score from pre-test, which are 17.4 (72.2 - 54.8). Meanwhile, the class percentage which pass the KKM in Post-test I is $43.7 \%$. It shows there are 11 students who passed the KKM and other was still low KKM. Because the criterion of action of success not achieves the target yet, the writer continues to the second cycle. After calculating the result of students' score post-test II, the mean score in the post-test II is 86.6. it means that there 15 students whose score pass the $\mathrm{KKM}$ criteria and there only 1 student is still under the KKM. The class percentage shows significantly improvement $93.75 \%$ from the pre-test $(25 \%)$. The second post-test in cycle II has fulfilled the target of classroom action research (CAR) success, it can be concluded that, by using Digital Storytelling technique in writing text significantly improves the students' skill in writing descriptive text. It can be seen from the calculation of percentage post-test II to pre test is $67.75 \%(92.75-25 \%)$.

Table 2. The Quantitative Data

\begin{tabular}{|c|c|c|c|}
\hline Components & $\begin{array}{c}\text { Pre- } \\
\text { test }\end{array}$ & $\begin{array}{c}\text { Post-test } \\
\text { I }\end{array}$ & $\begin{array}{c}\text { Post-test } \\
\text { II }\end{array}$ \\
\hline Score & 877 & 1155 & 1386 \\
\hline Mean & 54.8 & 72.2 & 86.6 \\
\hline Median & 51.5 & 72 & 88 \\
\hline Mode & 57 & 71 & 80 \\
\hline $\begin{array}{c}\text { Number of Students' } \\
\text { who got } \geq 70\end{array}$ & 4 & 11 & 15 \\
\hline $\begin{array}{c}\text { Students' percentage } \\
\text { who got } \geq \mathbf{7 0}\end{array}$ & $25 \%$ & $68.75 \%$ & $92.75 \%$ \\
\hline
\end{tabular}

In addition, the response of student after their taught by using digital storytelling is agree, it can be seen from the frequencies of item 110 (52.88) (see table 3). 
Table 3. Questionnaire for Students' response on Digital Storytelling

\begin{tabular}{|c|c|c|c|c|c|c|}
\hline$\#$ & $\begin{array}{l}\text { Strongly } \\
\text { Disagree }\end{array}$ & Disagree & Undecided & Agree & $\begin{array}{c}\text { Strongly } \\
\text { Agree }\end{array}$ & $\begin{array}{c}\text { Total of students } \\
\text { number }\end{array}$ \\
\hline 1 & 1 & & & 8 & 7 & \multirow{13}{*}{16} \\
\hline 2 & & 1 & & 7 & 8 & \\
\hline 3 & & 1 & 1 & 8 & 6 & \\
\hline 4 & & 1 & & 12 & 3 & \\
\hline 5 & & 1 & 2 & 7 & 6 & \\
\hline 6 & & & 2 & 10 & 4 & \\
\hline 7 & & & 2 & 10 & 4 & \\
\hline 8 & & & 2 & 8 & 6 & \\
\hline 9 & & 1 & 2 & 7 & 6 & \\
\hline 10 & & 1 & 1 & 9 & 5 & \\
\hline 11 & & 1 & 3 & 9 & 3 & \\
\hline 12 & & 2 & 1 & 7 & 6 & \\
\hline 13 & 1 & 1 & 1 & 8 & 5 & \\
\hline Total & 2 & 10 & 17 & 110 & 69 & 208 \\
\hline Percentage & $0,96 \%$ & $4.80 \%$ & $8.17 \%$ & $52,88 \%$ & $33,17 \%$ & $100 \%$ \\
\hline
\end{tabular}

\section{CONCLUSION}

After analysing and discussing the data on the previous chapter, then it can be concluded as follows, using Digital Storytelling in Writing Text Especially Descriptive Text was effective and useful for Students' Faculty of English Education Program at Saint Thomas University Medan 2017/2018. After the writer analyzed the data, it is found that the improvement of the students' percentage score from pre-test until post-test II is $68.75 \%$. Therefore, Digital Storytelling significantly improves students' score in writing Descriptives Text. Furthermore, it can be concluded that Digital Storytelling is effective to be used in teaching writing skill, especially in Descriptive Text. Based on the increase of the percentage, it is found out pre-test $(25 \%)$, post-test I $(68.75 \%)$, to post-test $(92.75 \%)$.

The response of using digital storytelling in improve writing skill especially Descriptive Text are categorized agree. It can be seen from the table 4,5 the percentage of item agree into $52,88 \%$ and the frequencies appear 110 times.

\section{SUGGESTION}

The students are suggested to continue this activity in mastery the technology. It will be very useful for them in increasing their ablility. to other researchers recomended to use Digital Storytelling on difference levels knowledge, further may also conduct research other genre of text to prove whether the use Digital Storytelling is effective or not.

\section{REFERENCES}

Anderson, J., \& Macleroy, V. 2016. Multilingual Digital Storytelling: Engaging Creatively and Critically with Literacy. New York: Routledge Taylor Francis and Group.

Burns, A. 2010. Doing Action Research in English Language Teaching. New York: Routledge Taylor and Francis Group.

Franzen, A.M., \& Allington, R.L. 2010. Handbook of Research on Reading Disabilities. New York: Routledge Taylor Francis and Group.

Mather, et. al. 2009. Writing Assessment and Instruction for Students with Learning Disabilities. San Fransisco: Jossey-Bass.

Ohler, J. 2008. Digital Storytelling in the Classroom: New Media Pathways to Literacy, Learning, and Creativity. California: Corwin Press.

Peacock, et. al. 2012. Practical Handbook of School Psychology: Effective Practices for the $21^{\text {st }}$ Century. New York: The Guildford Press.

Prierangelo, R., \& Giuliani, G. 2006. Teaching Students with Learning Disabilities: A Step by Step Guide for Educators. California: Corwin Press.

Xie, A., \& Huang, X. 2012. Advances in Computer Science and Education. New York: Springer. 